\title{
ANIMISM, VITALISM, AND THE MEDICAL UNIVERSITY OF MONTPELLIER
}

Bichat was one of the last medical theorists of any particular influence to insist uncompromisingly that physics and chemistry were separate sciences from physiology, making specious the application of their principles to the study of living processes. He saw the science of physiology as a unique discipline concerning itself with activities that have no counterpart in the sciences of the physical world. His statement in the Recherches physiologiques sur la vie et la mort that life is defined simply as "the totality of those functions which resist death", ${ }^{1}$ reveals more about his fundamental view of the organism than might appear at first glance. It tells us essentially that he saw each living body as an organic unit besieged by the forces belonging to the surrounding inorganic world. Although living forces are in organized matter only for a limited time, they are able to exert their dominance over physical ones. He would argue that it is by means of these combative vital forces that an organism grows, reproduces, is nourished, and responds to its environment. They leave the body very gradually if death is natural or lingering, or they flee quickly if it is accidental and sudden. Thereafter, the physical forces reassert their dominance, causing the organism to decompose and gradually to become one with the simpler, more stable and predictable realm of inorganic nature.

The conviction that life sciences are unique and to be distinguished from inorganic ones was widely shared by many of Bichat's contemporaries. It put him into a vitalist tradition that can be traced back at least to Aristotle. Eighteenth-century vitalists contributed a great deal to the development of the medical sciences and especially to their philosophy. In this chapter, I examine the evolution of certain vitalist notions, many of them developed by French physicians in the post-Newtonian period.

In 1700, the orthodox European medical man was a mechanist and a dualist, who believed that the living being is a composite of a material body and an immaterial soul. That soul, he assumed, oversees the voluntary, willed and rationally determined functions of the body. The remaining activity of that same body is automatic and involuntary. It occurs mechanically, for an organism, being part of nature, is basically no more than an intricate network of pulleys, pipes, and conduits whose activity is in accordance with mechanical and hydraulic principles. ${ }^{2}$ This view was soon challenged on the grounds that mere mechanism is not adequate to account for the complexity of living phenomena.

By 1800 , what is known in broad terms as the mechanist-vitalist debate was generally conceded to have been resolved in favour of the latter position. Indeed, Bichat's particular viewpoint was largely acceptable to most of his colleagues and con-

\footnotetext{
${ }^{1}$ Xavier Bichat, Recherches physiologiques sur la vie et la mort, Paris, Brosson, Gabon, 1801, p. 1.

${ }^{2}$ Two recent general works on medical philosophy in the enlightenment which touch on the topics I discuss here are Lester S. King, The philosophy of medicine, Cambridge, Mass., Harvard University Press, 1978; and François Duchesneau, La physiologie des lumières: empiricisme, modèles et théories, The Hague, Nijhoff, 1982.
} 


\section{Xavier Bichat}

temporaries. Among the physicians and physiologists in the latter part of the eighteenth century who considered themselves to be anti-mechanists, there may still have been some animists, so-called because they considered all living activity to be explained by the control of the body by a rational soul or anima. They shared a dualist theory of nature with the mechanists, for both believed that matter is inert substance and hence capable of motion only if subjected to an external force. Other vitalists postulated some specific life-conferring principle which coexists with the body and the soul as a kind of third substance overseeing the automatic and unconscious acts of life. Most other vitalists, especially after the mid-eighteenth century, were monists who believed that vital properties such as sensibility and contractility reside in the bodily parts themselves. Although they considered these properties to be distinct from and irreducible to the physical ones, they thought them to be intrinsic in the material of the body and a product of its organization.

Bichat and other monists are frequently labelled "organicists" or exponents of a theory of "organicism". Indeed, the term confers more precise information than the more general "vitalists", for it ensures that its adherents will not be confused with animists. Organicism was, nevertheless, a sophisticated form of vitalist theory, the end-product of a long debate concerning the nature of living matter. Many organicists whose views I shall consider admitted that they adjudged themselves to be intellectually and philosophically relatives of the animists, united to them in their mutual rejection of mechanism. I believe, therefore, that the more familiar vitalist label, albeit imprecise, is useful as long as we remember that vitalists were far from being a homogeneous group.

It should be clear by the time that we come to examine Bichat's vitalist theory in detail that he assimilated his fellow physicians' ideas with considerable ease. His largely synthetic work marries prevailing notions of the late eighteenth century to his own observations and assumptions. He was strongly influenced by the ideas of the Montpellier physicians, to whom is owed much of the credit for at least the earliest development of eighteenth-century vitalist theory. It all began at that ancient and venerable institution in 1737, when a young lecturer, François Boissier de Sauvages, introduced animist assumptions into his teaching, provoking outraged protest among his conservative and stolidly iatromechanist colleagues. In time, however, his viewpoint commended itself to growing numbers of faculty and especially to students. Although most of them did not long remain animists, the language of anti-mechanism was conceptually liberating.

The basic positions in the mechanist-vitalist dispute had been effectively drawn up by the mid-seventeenth century. Those persons who subsequently engaged in the debate about the nature of life and its activity owed their fundamental assumptions to the work of one of two men. Both mechanists and animists were heirs to the dualist and mechanical philosophy of René Descartes (1596-1650), while the organicists relied considerably on the work of Jan Baptista van Helmont (1577-1644). Both men felt themselves to be rebels against the stultifying remnants of the Aristotelian and Galenic notions which persisted in the schools they attended in their youth. Their respective philosophical speculations, however, produced vastly different results.

Born into an upper-class family in Brussels, Helmont received a degree from the 


\section{Animism, vitalism, and the Medical University of Montpellier}

University of Louvain, where he came into contact with the literature of the hermetic philosophy replete with mystical, alchemical, and astrological elements. Its language and imagery coloured his adult work. His writing, which addressed chemical, medical, and philosophical themes, was collected and published as the Ortus medicinae after his death. In 1661, it was translated into English and published under the title Oriatrike or physick refined.

Helmont claimed a profound disillusion with his youthful studies. In 1594, he wrote: "It dawned upon me that I knew nothing and that what I knew was worthless." Longing for truth and science, he recalled years later, he set out on a quest for certainty which led him away from the traditionalists and the schoolmen. A deeply religious man, he turned to God to show him a way out of his disillusion. "I prayed to the Prince of Life for the stamina to contemplate the naked truth and love it per se." The work of Galen, Hippocrates, Avicenna, and more recently of Fuchs and Fernel, he claimed, left him unenlightened. "I re-read the collection of my notes and recognized my poverty, and the labours and years I had consumed angered me." 3

About twenty years after Helmont's youthful rebellion, Descartes was similarly repelled by the shallowness and uncertainty of what he had been taught. Both men wanted to know wherein lay certainty and both rejected mere sensory evidence as misleading on the grounds that genuine knowledge is too elusive and confusing to be discovered merely with our five senses.

Helmont's enlightenment concerning the proper method to be used to acquire knowledge came to him as he sat beside his alchemical furnaces; Descartes' flash of insight occurred in a heated room in Germany. Descartes looked to clear and careful reasoning to show him how to distinguish what is true from that which merely appears to be so. He proceeded from the one truth which appeared to him to be irrefutable - "I think, therefore I am." "4 Helmont, on the other hand, claimed to have had a vision of his own indivisible and immortal soul receiving the light of knowledge from God. Believing that just such flashes of God-given insight are the basis of all knowledge, he sought intellectual and spiritual enlightenment through prayer and meditation. Accordingly, he eschewed the quest for nature's secrets by the application of reason, claiming that "our minds ought to be intellectual but not rational".s

The result of Descartes' fireside meditations was his dualist view of nature, a philosophy that divided the world into two distinct realms, matter and the immaterial. Descartes distinguished the material body from the mind, from life, and from its soul. According to him, the living body is properly understood as an intricate machine, a

\footnotetext{
3 Jan Baptista van Helmont, 'Studia authoris', Ortus medicinae, Amsterdam, L. Elzeverius, 1648, 16-19. Translated and quoted by Walter Pagel, 'The reaction to Aristotle in seventeenth-century biological thought', in Edgar Ashworth Underwood (editor), Science, medicine, and history, 2 vols., Oxford University Press, 1953, vol. 1, pp. 491-492.

‘ René Descartes, Discours de la méthode in Oeuvres de Descartes, ed. by Charles Adam and Paul Tannery, 11 vols., Paris, Vrin, 1973, vol. 6, pp. 31-40. Descartes' "nonvitalistic, material-mechanical" ideas are discussed by Thomas S. Hall, Ideas of life and matter, 2 vols., University of Chicago Press, 1969, vol. 1, pp. 250-263.

' Helmont, 'Venatio Scientiarum', Ortus medicinae, op. cit., note 3 above, pp. 24-32. For convenience, I have quoted throughout from the seventeenth-century translation of the original text. The translated reference is 'The hunting or searching out of sciences', Oriatrike or physick refined, London, L. Loyd, 1662, p. 15.
} 


\section{Xavier Bichat}

kind of clockwork, subject to the will and to thought which belong to the soul. This soul keeps the clockwork running. The source of its sensation and motion, it acts upon the body by means of a very fine intermediate sort of material known as animal spirits, which flow through the nervous system. Matter by itself is inert and incapable of self-motion. Descartes discussed this notion of physiological dualism and its consequences in his Traité sur les passions et sur l'âme of 1649, and in L'homme, which was published posthumously in 1664 .

Helmont did not so divide matter. To him, life is immanent in bodily substance rather than being externally conferred upon it. That is, Helmont was a monist. Although he believed in the existence of a soul that is both a spiritual and rational entity, he did not consider it to be an exclusive mover of the body. Far from being a machine, the body is, he believed, an entity having its source of motion within itself. ${ }^{6}$ Many of the most significant physiological debates of the next two centuries had to do with the conflicting viewpoints which derived from the adoption of either the monist or dualist view of matter.

Helmont's words are confusing largely because his imagery is free-wheeling, archaic, and by now, utterly unfamiliar. This is exacerbated by his rambling and incoherent writing style, which is equally difficult to follow in the original Latin and in its English translation. Until Walter Pagel produced his careful and painstaking analysis of Helmont's writings, his rambling thoughts were little understood, almost as obscure and mysterious as the faculties which he attributed to nature. ${ }^{7}$ Reading Helmont's writings, we confront a pervasive sense of life's mystery and of its complex inter-relationship with a universe throbbing with life and spiritual forces. He conferred upon the body a formidable array of chemical and spiritual forces whose essence is never accessible to mere scientific investigation.

By means of perhaps the most famous of all experiments, Helmont determined that water alone accounted for the weight gained by a tree during growth. He concluded that all matter may be reduced ultimately to water. Spiritual and immaterial objects, on the other hand, derive from a fundamental air. The transformation of water into a tree is due to activity of an in-dwelling seed which shares the nature of both spirit and matter, that is, of both air and water. Such seeds exist in all natural objects and they contain information which determines the future nature or form not only of an adult plant or animal, but of rock or metal as well. "Whatever therefore cometh into the

\footnotetext{
6 Pagel, op. cit., note 3 above, pp. 489-509.

7 Probably the single best source for understanding Helmont's complex theory is Walter Pagel's 'The religious and philosophical aspects of Helmont's science and medicine', Bull. Hist. Med., 1944, Supplement No. 2. In this work, Pagel argues that Helmont can properly be considered to be the first biochemist, since, with Paracelsus, he was one of the first to express vital phenomena in chemical terms as well as one of the first to use such instruments as the balance and thermometer in medicine. Pagel elucidates some of the complex and confusing terms that occur in Helmont's mystically inclined works. He demonstrates that Helmont's particular viewpoint owes much to his religious zeal. See also, Walter Pagel, Joan Baptista Van Helmont: reformer of science and medicine, Cambridge University Press, 1982. Other general sources are Lester S. King, The road to medical enlightenment, 1650-1695, London, MacDonald, 1970, pp. 37-62; King, op. cit., note 2 above, pp. 34-40, 125-134; Jacques Roger, Les sciences de la vie dans la pensée française du XVIII siècle, Paris, Colin, 1963, pp. 98-103; and J. Mepham, 'Johann Van Helmont, 1574-1644', in Rom Harré (editor), Early eighteenth-century scientists, Oxford, Pergamon, 1965, pp. 129-157.
} 


\section{Animism, vitalism, and the Medical University of Montpellier}

World by Nature, it must needs have the Beginning of its motions, the stirrer up, and inward director of generation."

In each seed there is a dormant archeus, a kind of sensitive soul which exercises a dynamic control of the body and provides its special character. "The Governor of generation", the archeus is a spiritual principle which transforms matter during growth and development. In the rendering of the seventeenth-century translator, "in things soulified, he walketh thorow all the Dens and retiring places of his Seed, and begins to transform the matter, according to the perfect act of his own Image. For here he placeth the heart, but there he appoints the brain, and he everywhere limiteth an unmoveable chief dweller, out of his whole Monarchy, according to the bounds of requirance of the parts, and of appointments." 8

Helmont believed that, like the heavenly sun, the bodily "principle of life", is centrally located, radiating its influence in all directions. Accordingly he said it resides in the upper part of the stomach ${ }^{9}$ where the mysterious process of transformation of food into flesh and blood begins. ${ }^{10} \mathrm{~A}$ kind of organic alchemist, the archeus presides over bodily processes by controlling many subsidiary archei residing in the organs and smallest bodily parts. They account even for illness. Infection, wrote Helmont, is due to the invasion of the body by foreign archei which alter and disrupt normal physiological processes.

Helmont considered the archeus to have come into being only with the fall of man from grace in the Garden of Eden. In addition to this mortal soul, man has an immortal one, the mens, centred in the brain. The two were wedded together until death became part of the human experience due to sin. Now the mens is tied to the body only as long as life is present. ${ }^{11}$ Although he tried to free himself from peripatetic imagery, we cannot help but be reminded here of the classical triumvirate of souls invoked to explain human activity and to distinguish different categories of life. So, like the Greeks, Helmont assigned consciousness and the intellect to the government of an immortal soul which acts on the body through a vital principle. A product of digestion, it rises to the brain to govern the senses and mental functions in general. ${ }^{12}$

Any attempt to organize or to summarize Helmont's thoughts inevitably produces some distortion. His words are a labyrinth of blas, ferments, gases, archei, seeds, and souls, all of whose actions intricately intertwine to control the processes of life and to link it to the spiritual realm. Still, persons like Pagel who have thoroughly studied his

\footnotetext{
${ }^{8}$ Helmont, 'Archeus faber', Ortus medicinae, op. cit., note 3 above, pp. 40-41; 'The chief or masterworkman', Oriatrike, op. cit., note 5 above, pp. 35-36.

'Helmont, 'Sedes animae', Ortus medicinae, op. cit., note 3 above, pp. 288-293; 'The seat of the soul', Oriatrike, op. cit., note 5 above, pp. 283-288.

${ }^{10}$ One of the most important works on this subject is 'Sextuplex digestio alimenti humani', Ortus medicinae, op. cit., note 3 above, pp. 208-225; 'A six-fold digestion of human nourishment', Oriatrike, op. cit., note 5 above, pp. 205-221. In this work the author examined what he believed to be a six-stage process of the transmutation of ingested food into bodily flesh. The first occurs in the stomach under the supervision of the spleen, which supplies a ferment to transform food into a cream. The second is in the duodenum, where bile neutralizes acidity; the third begins the process of making blood in the liver. And so on, until we reach the sixth stage of digestion, which occurs in "particular Kitchins of the Members", or in the tissues themselves. Each step is overseen by a "ferment", which is perhaps very roughly comparable to a chemical catalyst.

$"$ Helmont, 'Sedes animae', op. cit., note 9 above.

12 Helmont, 'Spiritus vitae', Ortus medicinae, op. cit., note 3 above, pp. 195-201; 'The spirit of life', Oriatrike, op. cit., note 5 above, pp. 192-197.
} 


\section{Xavier Bichat}

work see much there that was formative for the subsequent development of physiological theory. Among the physicians who were to express admiration for Helmont were many from Montpellier, including Théophile de Bordeu, a most important figure in the development of eighteenth-century vitalist theory. In our own time, Helmont has even received credit for being the founder of biochemistry because of his particular iatrochemical orientation and use of measuring instruments. ${ }^{13}$

Although Helmont was a creative and formative thinker, a great gulf separates him from his eighteenth-century successors. Between the time of his death in 1644 and the end of the century, the study of nature developed more profoundly and dramatically than at any other time in history. The method and the language of science as we know it largely took shape in those years with the emergence of the mechanical philosophy. Helmont's mystical and spiritual imagery and his visionary approach to the study of the organism became inadmissible. Furthermore, the separation of body and soul, of matter and spirit, which Descartes had posed for natural philosophy, thoroughly seared itself into the consciousness of European scientists and philosophers so that none of Helmont's successors could mingle the physical and spiritual realms as blithely as he had done.

Although the most striking achievements of the scientific revolution, which so profoundly altered man's conception of the natural world, was largely in physics and astronomy, the study of living nature was affected also. Perceiving the quantitatively based new physics to be remarkably predictable and coherent, many physicians and natural philosophers made it their goal to apply its assumptions and methods to their particular investigations. The most famous achievement in seventeenth-century medical science was the demonstration of the circulation of the blood. It is instructive to note that in his Discourse on method, Descartes took it to be supportive of the philosophy of biological mechanism even though Harvey himself was to emerge as a confirmed vitalist and even an Aristotelian. By the 1660s, there was emerging in Europe an iatromechanical school whose philosophy grew out of an intricate intertwining of physics and physiology. It was the epistemological and conceptual offspring of the mechanical philosophy. There was thereafter an increasing tendency to ask questions about the organism which invited answers based on mechanical, hydraulic, or corpuscularian assumptions. It was taken as axiomatic that in and of itself, matter is inert substance. The study of all natural phenomena was reduced to the examination of the motion of matter under the influence of forces external to itself. The greatest triumph of such an approach was, of course, Isaac Newton's demonstration of the laws of attraction in the Principia mathematica. Even before 1687 , however, iatromechanism was on its way to becoming the theoretical substructure upon which physicians and philosophers proceeded to construct a new organic theory. The approach, for example, of Helmont came to be discarded as meaningless. On the other hand, the mechanical philosophy of Descartes, Galileo, Gassendi, and a great many other natural philosophers spoke eloquently to contemporary needs and assumptions.

Iatromechanical works first appeared in large numbers in Italy among persons who

${ }^{13}$ Pagel (1944), op. cit., note 7 above. 


\section{Animism, vitalism, and the Medical University of Montpellier}

had been schooled in Galileo's mechanics. Physicians engaged in dialogue with mathematicians and students of mechanics, thereby producing a fruitful new view of organic function. Mathematics and physics were brought powerfully to bear on the study of human anatomy and physiology, and the image of the body as an intricate hydraulic machine began to preoccupy the students of living functions. Giovanni Borelli, for example, who held a post as lecturer in mathematics in Pisa in the 1650s, acquired an enthusiasm for medical questions from contact with the physicians Marcello Malpighi and Lorenzo Bellini. Probably because of this contact, Malpighi, in 1661, produced a strongly iatromechanist examination of lung anatomy and function, which he entitled Epistola de pulmonibus and dedicated to Borelli. In 1662, Bellini published Exercitatio anatomica de structura et usu renum, in which he tried to account for renal function entirely without recourse to such concepts as innate and attractive faculties. He wished to understand the parts as a mixture of solids and fluids with such quantifiable attributes as velocity, viscosity, and momentum. Another work by Bellini, his Opuscula aliquot of 1695, was actually organized into postulates, theories, and corollaries in obvious imitation of mathematics. Borelli's De motu animalium of 1680 is merely the most famous of a considerable number of works that treated the subject of the mechanics of muscular motion. In general, many works in that period appeared in which muscles, glands, the nervous system, and so on were analysed with the help of geometric language and presented in a mechanical and mathematical format. The Fellows of the Royal Society of Great Britain, as well as medical people in all of Europe, were seduced by the innovative new programme so that by the end of the seventeenth century, virtually every individual even minimally conversant with the new science had to give serious thought to the mechanical theory of living matter. ${ }^{14}$ The first substantial challenge to that position came early in the next century in the form of the animist philosophy.

The animist reaction occurred largely because the iatromechanical hypothesis left its proponents with the problem of having to explain what moves the living machine, at a time when it was taken ax axiomatic that matter is passive substance with no innate ability to generate motion. Willed and conscious activity such as that of voluntary muscles posed no particular problem. As most persons had always done, mechanists simply ascribed it to a soul or rational and even spiritual principle supposed to reside in the brain. So, in fact, did the animists and many vitalists. By so doing, they were accepting a long-standing albeit ambiguous definition of the soul. The psyche of ancient Greek usage was at once a spiritual, a vital, and a rational principle. Aristotle and Galen, for example, used the word to denote the source of mind, of consciousness and of life itself. As such it was a vital force or principle. In classical Latin, a distinction was made between the anima, which is a spiritual or vital principle, and the animus, which is a rational one. Europeans subsequently tended to conflate the terms such that the early translators of the Bible, for example, wrote only of the anima. Most modern European languages have only a single word to denote

${ }^{14}$ For a general discussion of mechanism, see Roger, op. cit., note 7 above, pp. 207-249; and King, op. cit., note 2 above, pp. 95-124. Two approaches to iatromechanism, the Galilean and the Cartesian, are discussed by François Duchesneau, 'Malpighi, Descartes, and the epistemological problems of iatromechanism', in M. L. Righini Bonelli and William R. Shea (editors), Reason, experiment and mysticism in the scientific revolution, New York, Watson, 1975, pp. 111-130. 


\section{Xavier Bichat}

soul. Similarly, in the eighteenth century, one word retained both its spiritual and rational connotations. Hence for physicians especially, the soul had a kind of dual role in the body. ${ }^{15}$

Most of the functions of the body, of course, are involuntary, automatic and unperceived. Much of the discussion has to do with the question of their origin. What is the source of power behind the heart, the digestive system, nourishment, and growth? We have seen how Helmont's archeus served to explain these functions. The mechanists deemed it sufficient to assume that the body is a massively complex automaton. Once set in motion, its parts interact to produce an involved series of motions which succeed one another of necessity. To use Descartes' own imagery, a living body is like an infinitely elaborate clockwork whose parts act automatically. Like a clock, it slows down and finally stops if left to itself. But that sort of explanation was altogether successful only so long as one posed only particular questions, and those in a particular way.

Borelli provides us with an example of the dilemma in which iatromechanists sometimes found themselves. In De motu animalium, he had difficulty in accounting for the action of the heart in purely mechanical terms. It is an involuntary organ and as such, it ought to be independent of the soul. Indeed, an excised heart is frequently observed to beat for a time. On the other hand, mental or emotional states are often perceived to affect its motion. This apparently conflicting evidence drove Borelli to speculate that, in the case of the heart, the soul is acting unconsciously. ${ }^{16}$ The identification of a growing number of such inconsistencies in the mechanists' accounts provided fertile ground for an anti-mechanist reaction.

The mechanist-animist debate largely took shape in the first four decades of the eighteenth century. It can be illustrated by a glance at the notions of three men who, in those years, were perhaps the most famous physicians in Europe. They are Friedrich Hoffmann (1660-1742), a Cartesian; Herman Boerhaave (1668-1738), a mechanist; and Georg Ernst Stahl (1659-1734), an animist. The problems to which they addressed themselves and the divergent hypotheses which they advanced to deal with them laid the basis for the speculations and the experiments of many enlightenment physicians and philosophers, including the Montpellier physicians and Bichat.

Hoffmann completed his medical training in 1684. A year later, while travelling in Europe where he met the English chemist Robert Boyle, he received an invitation from Frederick III, the Elector of Brandenburg and the future King Frederick I of Prussia, to become the Professor of Medicine at a new university just established in his native Halle. Some nine years later, Hoffmann, in turn, invited Stahl to join him in

\footnotetext{
15 Theodore Blondin, 'Du vitalisme animique. Études générales devant servir d'introduction à la physiologie de G. E. Stahl', Oeuvres médico-philosophiques et pratiques, 6 vols., ed.by Theodore Blondin, Paris, Baillière, 1860, vol. 3. Blondin demonstrates the trap awaiting the unwary historian who does not know of the confusion surrounding the definition of the word soul. Blondin particularly approved of Stahl's animism, arguing that he had struck a blow on behalf of God and religion in a world losing its faith. He rhapsodized about Stahl's piety and his virtuous attack on atheism and materialism, although he confused theology and physiology by so doing. See also, Roger K. French, Robert Whytt, the soul, and medicine, London, Wellcome Institute, 1969, pp. 117-148; and L. J. Rather, 'G. E. Stahl's psychological physiology', Bull. Hist. Med., 1961, 53: 37-49.

${ }_{16}$ This example comes from Roger K. French, 'Sauvages, Whytt and the motion of the heart: aspects of eighteenth-century animism', Clio medica, 1972, 7: 35-54, see 37-38.
} 


\section{Animism, vitalism, and the Medical University of Montpellier}

Halle. But long before Stahl wrote anything on the subject of the living organism, Hoffmann was speculating in print on the nature of the living body.

His Fundamenta medicinae of 1695 was a textbook of general medical theory, ranging over physiology, pathology, symptomatology, hygiene, and therapeutics and touching upon the methodology appropriate to each. It was intended to provide its readers, many of whom were medical students, with a general viewpoint on medicine. That viewpoint turned out to be iatromechanism wedded to many of Hoffmann's Cartesian assumptions about mind and matter. ${ }^{17}$ In the introduction, he affirmed a wish that medicine should become a science employing a "simple, clear mathematical method". Nature, he wrote, is mechanical. Matter and motion are its first principles. "Changes and alterations of the entire universe are due to motion." Accordingly, God's role in His creation is that of a supreme mechanic, the "prime mover of all things [who] ... produces things by statics and mechanics and maintains everything in its equilibrium."18

It seems to follow from such a viewpoint that "Medicine is the art of properly utilizing physico-mechanical principles in order to conserve the health of man or to restore it if lost"; "Like all of nature, medicine must be mechanical ... . The first principles of mechanics are matter and motion"; and finally, "Life is achieved by causes which are wholly mechanical. The mind does not bring life to the body, nor is life oriented to the mind, but rather to the body." 19 So it is, for example, that the production of bodily humours is explained solely by filtration. "The viscera do not separate out the excremental humours through any ferment that precipitates the humours to be secreted, but all secretion of the bile, urine, sweat, phlegm, saliva, is accomplished by mechanical means and a particular manner of filtration."20

Since the passivity of matter was a fundamental tenet of the mechanical philosophy, Hoffmann had to address the question of how the material parts are to be activated. He assumed that some spirit or prime mover must exist to move the machine. While life is present, he wrote, there is a continuous movement of the fluid parts of the body through the solid ones. These fluids, including the animal spirits, the blood, and the lymph, excite the solid parts inducing them to perform appropriate movements. Health exists when the motion is well ordered. Death is simply the destruction of motion. With most of his contemporaries, Hoffmann believed that the initial source of the motion is the soul or anima which possesses both material and spiritual properties. His own words say it best:

In our machine, the first principle of motion is the soul which you may, if you want, designate as nature, or spirit endowed with mechanical powers, or a most subtle ethereal matter acting in an ordered and specific fashion....

The first cause of the powers existing in the soul [anima] is God himself, on whom all things depend,

${ }^{17}$ The work is easily accessible since Lester S. King's English translation of it as Friedrich Hoffmann, Fundamenta medicinae, London, MacDonald, 1971. King summarized Hoffmann's viewpoint in an 'Introduction', pp. iv-xxv. See also, King, op. cit., note 2 above, pp. 34-40. A more ambitious analysis of Hoffmann's mechanist system is presented by Duchesneau, op. cit., note 2 above, pp. 32-64.

${ }^{18}$ Hoffmann, 'To the reader', op. cit., note 17 above, pp. $1-4$.

19 Ibid., pp. 5-11.

${ }^{20}$ Ibid., pp. 28-34. This quotation is interesting for our purposes because some fifty years later, Théophile de Bordeu would deal a decisive blow to the iatromechanist viewpoint by using the evidence produced by glandular activity, as we shall see later in this chapter. 


\section{Xavier Bichat}

including the existence and functions of our soul.

The animal spirits are not the vital principle or soul itself but the soul uses them as instruments for achieving its functions.

The functions of the soul are to move the spirits and to direct them to produce particular motions. ${ }^{21}$

In addition to its mechanical capacities, the human soul is endowed with the power of thought and reason. It is an "immortal substance stemming from the decree of God himself'.22

Animal spirits exist largely in the nerves. Too fine to be seen, they are the will's instrument for achieving sensation and muscular motion. In response to the soul's direction, they move in accordance with mechanical principles and physical laws. Other words written by Hoffmann, however, concede that the animal spirits seem to possess some capacity for self-motion. "The animal spirits", he wrote, "have a power impressed by God, not only of moving themselves mechanically, but doing so by choice, purposefully and toward a definite goal. This power is called the sensitive soul, and it exists entirely in the most subtle fluid of the brain." Focused in what he called a "common sensory" in which external impressions are gathered, the "animal spirits are directed and pass out to all the parts which would be animated by sensation and motion". ${ }^{23}$

Hoffmann's work is an example of the sort of dilemma which iatromechanism, rooted in assumptions about inert matter, created for its adherents. The body required a non-material source of motion. When they considered how pure spirit is able to impose its will upon pure matter, they usually imagined some intermediate substance combining the properties of both spirit and matter. By so doing, they were according the capacity of self-motion to at least some matter, so as to solve the difficulties posed by the belief that it is inert.

Because Hoffmann considered himself to be a Cartesian mechanist, we treat him as such. It is true, however, that our perception of his notions can deviate from Hoffmann's own. It seems clear to me, for instance, that although Hoffmann professed to disagree with the animist position, he moved perilously close to it when he cast the soul into the role of prime mover. How close can be seen by a comparison with Stahl, who put his provocative animist notions of physiology into print some ten years after the Fundamenta medicinae at a time when the two men were colleagues at Halle. Stahl's fundamental tenet was that the soul is the exclusive source of all bodily motion, voluntary and involuntary alike. Often, it is difficult to say precisely where their notions differed, disagreement apparently having more to do with emphasis than with substance. It remains true, however, that in spite of the apparent correspondence between many of the two men's ideas, they considered themselves to be separated by a wide theoretical gulf. ${ }^{24}$

However influential the Fundamenta medicinae might have been initially, it was displaced in importance by the work of Boerhaave, especially by his Institutes which

${ }^{21}$ Ibid., pp. 11-13.

22 Ibid.

${ }^{23}$ Ibid., pp. 23-28.

${ }^{24}$ For a discussion of the relationship between Hoffmann's and Stahl's ideas, see Lester S. King, 'Stahl and Hoffmann: a study in eighteenth century animism', J. Hist. Med., 1964, 19: 118-130. For a further discussion of Hoffmann's work, see King, op. cit., note 7 above, pp. 181-204. 


\section{Animism, vitalism, and the Medical University of Montpellier}

appeared in 1707. Boerhaave's very name came to be synonymous with iatromechanism and his reputation as a teacher was unsurpassed in his lifetime. He attracted students from Europe and North America to Leiden. Because many disciples spread his fame widely, his notions governed medical instruction as far away as North America. William Cullen reported that in Edinburgh, as late as in the 1760s, he was advised not to differ from Boerhaave for fear of hurting himself or his university.

Cartesian notions had penetrated the Leiden medical school before Boerhaave received a chair there in 1703. At his inaugural address to the university, he dedicated himself to fixing the mechanist thesis upon a firm foundation of observation and experimentation. His methods must have been deemed appropriate, for his school quickly became the most celebrated in Europe. ${ }^{25}$

In a work discussing 'The nature and principles of physiology', we find Boerhaave's position expressed as follows:

The solid Parts of the human Body are either membranous Pipes, or Vessels including the Fluids, or else Instruments made up of these and more solid Fibres, so formed and connected, that each of them is capable of performing a particular Action by the Structure, whenever they shall be put in Motion; we find some of them resemble Pillars, Props, Cross-Beams, Fences, Coverings, some like Axes, Wedges. Leavers, and Pullies; others like Cords, Presses or Bellows; and others again like Sieves, Strainers. Pipes, Conduits and Receivers; and the Faculty of performing various Motions by these Instruments is called their Functions; which are all performed by Mechanical Laws, and by them only are intelligible. ${ }^{26}$

How then does one account for the motion of pipes, sieves, and presses? From what primary impulse do the bodily functions proceed? Emphatic though he was that man is a composite of mind and body, Boerhaave did not speculate overmuch in his writings about the nature of the mind-body relationship, simply acknowledging it to be a "harmony established by God". The material and spiritual components of the body are such that "each has a Life, Actions and Affections differing from the Other". Nevertheless, "there is such a reciprocal Connection and Consent between the particular Thoughts and Affections of the Mind and Body, that a Change in one always produces a Change in the other and the reverse." But unconscious bodily functions depend upon the mind not at all. "There are some Actions performed by the Body without the Attention, Knowledge or Desire of the Mind, which is neither concerned therein as the Cause or Effect of these Actions."

Boerhaave may have briefly flirted with the notion that matter in an organized body might have a life or motive principle apart from the rational one. At least, that is a possible interpretation of the following words:

The Life of the Body is, 1. To generate Motion under particular Circumstances, as the Loadstone approaches to Iron. 2. For its constituent Parts to attract each other, from whence proceeds that Resistance to the Force of external Bodies, or Vis Inertia. ... In a Word, the Life of the Mind is to be conscious.

${ }^{25}$ Boerhaave's influential viewpoint is discussed in a number of sources including Gerrit A. Lindeboom, Hermann Boerhaave, the man and his work, London, Methuen, 1968; Lester S. King, The medical world of the eighteenth century. University of Chicago Press, 1958, pp. 59-121; Hall, op. cit., note 4 above, vol. I, pp. 367-390; and Duchesneau, op. cit., note 2 above, pp. 103-140.

${ }^{26}$ Herman Boerhaave, 'The nature and principles of physiology', Dr. Boerhaave's academical lectures on the theory of physic, being a genuine translation of his Institutes as dictated to his students at the University of Leyden, 6 vols., London, W. Innys, 1757-73, vol. 1, pp. 80-85. The emphasis in this and other quotations is the author's own. 


\section{Xavier Bichat}

But unfortunately, Boerhaave dismissed ultimate questions about life and matter on the grounds that the true physician properly applies himself to restoring health. So it is that "the primary physical Causes ... and the ultimate metaphysical Causes ... are neither possible, useful, or necessary to be investigated by a Physician; . . . The Origin of Motion is to be look'd for in God; if we substitute any other primary Cause, we do him Injustice."27

As we have seen, the ease of application of mechanist or animist assumptions in the eighteenth century depended upon the nature of the questions one asked of the organism. Iatromechanists tended to be most successful when they studied the functions of specific parts. Their approach lent itself to examining, for example, muscle contraction, blood flow, and glandular fltration. It was less satisfactory when one focused upon the organism with a view to understanding its integrated and apparently purposeful activity. Although a mechanist might be convincing when he discussed the various stages of digestion, he was less persuasive when he addressed the process of nutrition. He constantly ran the risk of oversimplifying and even ignoring such complex activity as adaptation, co-ordination, and growth. ${ }^{28}$

Stahl addressed just such integrated and long-term processes in his writings. At a time when an anti-mechanist stance was so provocative as to border on the revolutionary, he rejected mechanism as an inadequate tool for understanding living phenomena. Stahl, who was a professor at the University of Halle from 1694 to 1715 , published most of his medical writings between 1706 and 1708. The overall view of the living body that emerges from them is that of a complex, dynamic, and infinitely reactive structure. ${ }^{29}$ It is this incessant but purposeful activity which seems to have particularly impressed him and to have directed his speculations. He believed that the reactive quality belongs to living things alone among all natural objects and it in that reaction that he searched for clues concerning the special features which distinguish life from non-life.

In a work on the subject, De vera diversitate corporis mixti et vivi, Stahl remarked that the most fundamental feature of a living body is its unique complexity of form and organization. "If a mixture, an ordinary chemical composite is homogeneous and stable, a living body is naturally heterogeneous and condemned to corruption if it is abandoned to itself." 30 There is an enormous variety among living species simply because each species has its unique and complex mixture of physical elements. This very mixture is the basis of all life-related functions. It follows, therefore, that one

${ }^{27}$ Boerhaave, 'Of the parts and principles of physic', ibid., pp. 51-79.

${ }^{28}$ Discussed by Lester S. King, 'Basic concepts of eighteenth-century animism', Am. J. Psychiat., 1967, 124: 105-110; and by Hilde Hein, 'The endurance of the mechanism-vitalism controversy', J. Hist. Biol., 1972, 5: 159-188. See also, Lester S. King, 'Rationalism in early eighteenth-century medicine', Bull. Hist. Med., 1963, 37: 257-271.

${ }^{29}$ Stahl's medical theory is discussed in a number of works, the earliest being by Albert Lemoine, Le vitalisme et l'animisme de Stahl, Paris, Baillière, 1864. See also, Roger, op. cit., note 7 above, pp. 427-431; Hall, op. cit., note 4 above, vol. I, pp. 351-366; François Duchesneau, 'G. E. Stahl: anti-mécanisme et physiologie', Archs. int. Hist. Sci., 1976, 26: 3-26; and more recently, Duchesneau, op. cit., note 2 above, pp. 1-31. Part of Duchesneau's purpose is to examine the epistemological aspect of Stahl's notion of physiology, which emerged at the time when the frontier between physiology and physics was not yet clear.

${ }^{30}$ Georg Ernst Stahl, Demonstratio de mixti et vivi corporis vera diversitate, Halle, 1738, $\S \mathrm{X}-\mathrm{XV}, \mathrm{pp}$ 70-75. In the French translation, the reference is Mixte et vivante in Oeuvres medico-philosophiques, op. cit., note 15 above, vol. 2, pp. 366-376. 


\section{Animism, vitalism, and the Medical University of Montpellier}

ought not to attempt to understand life apart from that mixture, and also that it is important to try to determine what sustains it.

Stahl was shocked, he wrote, to find that nowhere among the mechanists was there any attempt to arrive at a logical definition of life, ${ }^{31}$ which he defined as "the conservation of an eminently corruptible body, the faculty or force with whose aid the body is sheltered from the act of corruption". ${ }^{32}$ Notice that the key word is "conservation". That is, though the body is a corruptible mixture, life consists not in that mixture itself but in its preservation. Indeed, like Stahl, we observe daily that life seems to be the cause and not the consequence of organization. The breakdown of a body into its elements begins as soon as some mysterious living force or essence leaves the organism at death. Organization fails, causing the decaying parts gradually to merge into their inanimate surroundings.

Stahl believed that this conserving function belongs to the anima. It and it alone activates the passive matter of the body. It oversees the unwilled as well as the willed, the unconscious as well as the conscious action. Stahl avoided many of the conceptual difficulties that afflicted the mechanists by treating the distinction between conscious and automatic acts as artificial. He observed, for example, that such emotions as joy, fear, and anger affect the functions of organs which are not normally under control of the will. He did not even deny that living activity proceeds in accordance with mechanical principles. His emphasis in his writings, however, was on the soul's direction.

The soul acts on the body to conserve it, Stahl wrote, by means of motion. Fluids appear to mediate between the solid body and the immaterial mind:

It is by motion that the human soul accomplishes its work in and on the body, as powerfully and as long as it can, but one cannot say in an absolute and true manner that motion is life. It is again by the circulatory motion of humours that nature produces the living phenomena; but that is not to say that the circulation of humours is life, because this is but a simple instrument, ... Similarly, excretions and secretions do not constitute life. They are really only its supreme and most immediate instrument, by means of which nature can reject whatever is improper or foreign to it, and retain and assimilate whatever is useful to it for the conservation of the body. ${ }^{33}$

Motion is also at the root of nervous activity. The phenomena of sensation occur through a tonic or very sensitive tensile movement in the delicate nerves of sensory organs. ${ }^{34}$ In the composite body, the soul needs the body as much as the body needs the soul. "The soul cannot, indeed, have any sensation of a thing, and consequently any thought or knowledge with regard to a sensible present object without the intermediary of the sensory organs; it cannot furthermore effect an act or execute its will without the aid of corporeal organs." 35

\footnotetext{
${ }^{31}$ Georg Ernst Stahl, Paraenesis ad aliena a medica doctrina arcendum, Halle, 1738, §XVII, p. 50; Paroenesis in Oeuvres médico-philosophiques, op. cit. note 15 above, vol. 2, p. 224.

${ }^{32}$ Georg Ernst Stahl, Theoria medica vera, Halle, 1738, pp. 200-201; Vrai théorie médicale in Oeuvres médico-philosophiques, op. cit. note 15 above, vol. 3, p. 43. We also read that the heterogeneous body is "condemned to corruption if abandoned to itself", in Mixti et vivi, op. cit., note 30 above, $\S \mathrm{V}-\mathrm{XV}, \mathrm{pp}$. 68-75.

${ }^{33}$ Stahl, Paraenesis, op. cit., note 31 above, p. 46; Paroenesis, op. cit. note 31 above, p. 169.

${ }^{34}$ Stahl, Theoria medica vera, op. cit., note 32 above, pp. 421, 438; Vrai théorie médicale, op. cit., note 32 above, vol. 3, pp. 428, 456-457.

${ }^{35}$ Ibid., p. 210 in the Latin text and pp. 46-48 in the French one. The same idea is expressed in Disquisitio de mechanismi \& organismi diversitate, Halle, 1738; Mécanisme et organisme, in Oeuvres médicophilosophiques, op. cit., note 15 above, vol. 2, pp. 219-226.
} 


\section{Xavier Bichat}

One of the most difficult notions to comprehend in Stahl's work is his assertion that the soul acts wisely and consciously in the body. How then does one account for the fact that most of the body's functions are unconscious and automatic? Stahl's reply was that all activity is conscious in a newborn infant. It ceases to be so largely when it becomes habitual. ${ }^{36}$ It was surely the least persuasive part of his hypothesis. At least mechanists had avoided that particular difficulty when they separated the psychic functions from the automatic ones.

Whatever the limitations of his conceptual system might be, Stahl paved the way for a revision of the fundamental principles of physiological theory. Although it was not obvious early in the eighteenth century, contemporary mechanical descriptions of living processes were too limited to provide a basis for continuing progress in the life sciences. Stahl's approach, on the other hand, paved the way for the production of an autonomous science of man. ${ }^{37}$ Anti-mechanism was the proverbial idea whose time had come. Perhaps it was even somewhat ahead of its time, for when Stahl's work first appeared, it was largely dismissed or disregarded. Boerhaave simply denied that animism had anything to do with medicine, while Hoffmann preferred his animal spirits, subtle fluids, indwelling organizing forces, or, apparently, whatever else he needed to avoid the problems posed by a ubiquitous soul.

Animism first took root in the south of France among the medical faculty of the University of Montpellier who were, like their counterparts elsewhere, mechanistically inclined. Perhaps because of their school's own considerable reputation, students from Montpellier did not flock to Leiden in the same numbers as did those from elsewhere. Boerhaave's biographer, Lindeboom, suggests that the great man's reputation was less in France than elsewhere, ${ }^{38}$ permitting his ideas to be more easily displaced there. In any case, once established, animism set Montpellier's physicians off in directions different from those dominating other schools. Even when animist notions had been displaced by organicist theories, Montpellier physicians continued to recall Stahl as an intellectual prophet, crediting him with the immeasurably important task of freeing physiology from iatromechanist excess.

Animism, or at least a mechanism greatly modified by animist notions, was introduced into Montpellier by François Boissier de Sauvages (1706-67), a flamboyant and effusive man upon whom even the heavens smiled. He was born, we read in a eulogy, at the precise time of a total eclipse of the sun. Whether or not this was propitious, Sauvages in time acquired a considerable reputation as a physician and a teacher, both in France and abroad. Eight years after receiving a doctorate from the University of Montpellier, he obtained, in 1734, a position as a médecin survivancier to a member of the faculty. As such, he was expected to assist his professor and to fulfil his professional obligations whenever necessary. In the eighteenth century, getting a professional position at Montpellier was a mercenary business. As often as not, the man who occupied a well-paid chair spent most of his time practising medicine lucratively elsewhere, while his survivancier performed all his professional

${ }^{36}$ Stahl, Mechanismi \& organismi, op. cit., note 35 above, pp. 118-119; Mécanisme et organisme, op. cit., note 35 above, pp. 338-339.

${ }^{37}$ Roger, op. cit., note 7 above, p. 430; Duchesneau, op. cit., note 29 above; and Duchesneau, op. cit., note 2 above, pp. 1-31.

${ }^{38}$ Lindeboom, op. cit., note 25 above, pp. 355-374. 


\section{Animism, vitalism, and the Medical University of Montpellier}

duties. In 1740, on the recommendation of François Chicoyneau, first physician to the king, Sauvages was appointed to a lectureship in botany. But it was understood that he would remain in the position only until 1758, when Chicoyneau's grandson would reach the age of twenty-one, at which time he would take up the position. Indeed, even though Sauvages became Royal Professor of Botany in 1751, he gave up the position, as expected, in 1758. Nevertheless, he remained associated with Montpellier for his remaining years. ${ }^{39}$

As a student, Sauvages would have listened to the lectures of such iatromechanists as Jean Astruc, Antoine Didier, and Pierre Chirac. About 1737, however, he began to adopt an animist viewpoint in his lectures. Many student theses written under his direction after this date tend to display a pointedly animist viewpoint. His new orientation did not go unnoticed by his colleagues. Bordeu, who was a medical student at the time, reported that the heated arguments lasted some six or seven years..$^{40}$ In time, however, the new approach triumphed, and Montpellier became so proud of its theoretical innovation that it too became a stultifying orthodoxy. In the middle of the eighteenth century, however, it was liberating. Its assimilation by persons hitherto iatromechanical is perhaps a tribute to Sauvages' persuasiveness as well as to the limitations perceived in the older theory.

This is not to say that Sauvages turned his back on mechanical principles. In all his numerous rambling works on many subjects he consistently affirmed that a physician ought to understand and to borrow the principles of philosophy, mechanics, mathematics, physics, and geometry, for they permit one to determine the capacity of vessels, the strength of solids, and so on. "I am persuaded", he wrote, "that one can establish no certain theory of the animal economy without the knowledge of Physics and Mathematics and that a man who will unite to the knowledge of these sciences those of Anatomy and materia medica will be more able to practise medicine with success than another man." 41 While he did not wish to return to pre-mechanistic conceptions of the living world, however, he denied that mechanism and physics were in themselves sufficient to study it.

Mechanistic explanation dominated a Dissertation sur la nature et la cause de la rage, commissioned by the French government. The blood of a rabid animal, wrote Sauvages, is observed to become sticky, because rabid venom contains "volatile alkaline particles" which coagulate blood. In the first stage of the disease, he wrote, heart contractions will become weaker with such blood. Its decreased quantity and velocity reduces its friction in the vessels, thereby forcing down the animal's temperature and producing a muscular lassitude. This weakness is countered by an increased activity on the part of the nervous system. Nerves are insinuated with the rabid venom, increasing the elasticity of their fluid and hence the victim's general

\footnotetext{
${ }^{39}$ Two largely biographical studies are: Étienne Hyacinthe de Ratte, 'Éloge de Monsieur de Sauvages', in Les chefs d'oeuvres de Monsieur de Sauvages, 2 vols., Lyons, V. Réguilliat, 1770, vol. I, pp. xxv-Ixxxvi; and Louis Dulieu, 'François Boissier de Sauvages (1706-67)', Rev. Hist. Sci. applic., 1969, 22: 303-322.

${ }^{40}$ Théophile de Bordeu, 'Recherches anatomiques sur la position des glandes et leur action', in Oeuvres complètes, 2 vols., Paris, Caille et Ravier, 1818, p. 204. Also mentioned by Alexis Alquié, Précis de la doctrine médicale de l'École de Médecine, 4th ed., Montpellier, Frères Ricard, 1846, pp. 19-23.

${ }^{41}$ François Boissier de Sauvages, 'Discours préliminaire', Nosologie méthodique ou distribution des maladies en classes, en genres, et en éspèces, 10 vols., Lyons, J. M. Bruyset, 1772, vol. 1, pp. 73-83
} 


\section{Xavier Bichat}

sensibility. A person in this condition tries to shut out all impressions, which by now seem intolerably strong. He is hydrophobic because his throat is very sensitive even to the water which he craves desperately. As the disease intensifies, violent muscular force produces insomnia, copious perspiration, an accelerated pulse, and general overactivity. And so he continued, always mechanistically. ${ }^{42}$

Iatromechanism alone, however, was insufficient to account for the action of drugs. A Dissertation sur les médicamentes of 1752 provides an illustration of Sauvages' particular modification of mechanism. All ingested products including drugs, food, and poisons are first broken down mechanically into their parts or molecules. One large pill, he wrote, acts ten times more slowly than a thousand small ones because the latter have ten times the surface area of the former. A drug that acts selectively upon the stomach and intestines does so simply because its particles do not pass into lacteals or other small vessels. Mercury acts upon the head because its molecules, heavier than blood, enter the straight carotid artery rather than turning the angle of the aorta and flowing towards the limbs, and so on. With a multitude of examples to back him up, Sauvages claimed that drugs act "by means of mechanical principles such as mass, velocity, the structures of the parts, calibre size and so on".

The significant point for our purposes, however, is that "Drugs act, not on a pure machine, but upon an animated one". A tiny bit of "tabac d'Espagne". Sauvages wrote, dissolves when it touches the membranes of the nose, producing violent sneezing. A grain of emetic causes the stomach to lift a column of water nearly two feet with a force calculated to be equivalent to thirty pounds of water falling from the same height. Since machines do not multiply forces, these minuscule causes must produce their powerful effects because they act through a living motor. ${ }^{43}$

He discussed the nature of the living motor at length in the preliminary discourse to his Nosologica methodica of 1769, in which he classified illnesses in imitation of Linnaean categories. "Man", he wrote, "is an aggregate or a being made up of a living soul and a mobile body." The former is the critical motor (puissance motrice) which moves the normally inert bodily mechanism. He claimed that in a cadaver, such as a recently drowned man, the mechanism is intact. We find therein all the faculties common to plants, which he believed act purely out of mechanical necessity, and to hydraulic machines. The fluids are the same. It is dead because there is no soul.44 "Daily experience shows us that the soul is the principle of understanding, of appetite, of muscular motion, of the motion of the heart and of respiration, because these motions persist so long as it is present and cease when it is absent."45

A single substance, according to Sauvages, the soul possesses three faculties - it knows, it desires, and it moves. Their distribution and complexity vary between man and the animals. For example, the first faculty which is the source of sensation, imagination, and memory contains, only in man, the capacity for reflection, reason, and abstraction. Whereas all animals experience desire, it is modified by the will in

${ }^{42}$ Sauvages, 'Dissertation sur la nature et la cause de la rage', Chefs d'oeuvres, op. cit., note 39 above, vol. 1, pp. 15-105.

${ }^{43}$ Saukages, 'Dissertation sur les médicaments', ibid., vol. 2, pp. 1-97. The quotation is from pp. 9-11.

44 Ibid., pp. 9-11. Also Nosologie méthodique, op. cit., note 41 above, vol. 1, pp. 168-216.

45 Ibid., p. 219. 


\section{Animism, vitalism, and the Medical University of Montpellier}

humans alone. So it is, wrote Sauvages, that the surgeon depends upon his patient to volunteer to the knife and the criminal walks to the gibbet. The third or motive faculty is the source of all bodily functions whether these are voluntary or involuntary. ${ }^{46} \mathrm{By}$ resorting to this subdivision, Sauvages was able to account for the variety of physiological response without multiplying motive principles.

Although the soul acts principally in the brain, according to Sauvages, it cannot be confined to it. This is confirmed by an excised heart beating, by the moving parts of a dissected lizard, and so on. Under the soul's control in the intact animal, such motions are attributed to remnants of the nervous fluid which mediates between the soul or the brain and the parts. ${ }^{47}$ Like many others, Sauvages tried to solve the problems created by the theory of a nervous fluid by assigning it both material and immaterial properties. New work on the subject of electricity offered Sauvages new possibilities for speculating about its special nature. Like light, he wrote, a nervous impulse travels at least thirty times more quickly than sound. Nervous fluid may be a kind of "elemental fire", electrical in nature. Like electrical fluid, it is very finely material, permitting it to travel over fibres to the parts much more quickly than any other material known. ${ }^{48}$

Clearly, Sauvages cannot be strictly labeled a Stahlian. His commitment to animism was, I suspect, far less fundamental than Stahl's had been. Stahl became an animist because he was preoccupied with integrated and complex activities directed towards some goal, such as occur only in living bodies. He considered inorganic nature to be a world apart. Sauvages was somewhat more cavalier than Stahl in employing the notion of the anima. He called upon it as a merely convenient explanatory device, a kind of physiological unknown to be invoked whenever the possibilities of the mechanist approach were exhausted. It was the animal motor, the device that moves muscles and confers a mechanical advantage whenever one is needed. Indeed, the anima that Sauvages postulated is in many ways a somewhat uncomfortable explanatory device. Its role was far more nebulous and vague than the purely voluntary and rational one assigned to it by the mechanists. Neither was it as noble or powerful as that omniscient instrument which Stahl believed integrates, calculates, and consciously oversees every living act. It seems, in fact, that it existed largely to fill in the gaps which mechanism left in Sauvages' understanding.

A precocious young man, Théophile de Bordeu (1722-76), began to attend Sauvages' lectures shortly after he began teaching at Montpellier. Caught in the middle of the controversy aroused by his teacher's unorthodoxy, Bordeu assented to his criticism of the purely mechanical approach to life. He was not satisfied, however, with the animist alternative. He opted instead for a monist anti-mechanism which owed a great deal to the ideas of Helmont and of Francis Glisson, who had written at length on the subject of the irritability and reactivity of living fibres. ${ }^{49}$ Bordeu's approach was thoughtful, creative, and sufficiently novel to provoke great interest among his fellow physicians. More than any other physician, he was responsible for

${ }^{46}$ Ibid., pp. 216-255.

"Sauvages expressed interest in the animist notions of Robert Whytt, including his contention that the soul is extended throughout the body. For a discussion of this interest see French, op. cit., note 16 above.

${ }^{48}$ Sauvages, op. cit., note 42 above, pp. 54-71.

${ }^{4}$ See Chapter III. 


\section{Xavier Bichat}

discrediting iatromechanism and the Boerhaavian approach to medicine. Bordeu directed physiological investigation into a new and more productive direction which was to come into vogue in the middle of the century. He was to be undoubtedly the single most important influence on Xavier Bichat.

Bordeu was born in the south of France into a family whose men had been physicians for some four generations. He earned the title of medecin-chirurgien from Montpellier in 1744. Intensely ambitious and covetous of a specialization in the diseases of the rich, he left the south of France for the capital. To practise medicine in Paris, however, the diploma from Montpellier was not sufficient unless one enjoyed the patronage of a member of the royal family. Having no princely client, Bordeu wrote three theses for the Faculté de Paris, took an examination, and paid them a fee of fifty louis. By the time he reached the age of thirty, he was established at the Hôpital de la Charité. He is widely reported to have been a handsome, elegant, fluent, caustic, and somewhat metaphysically inclined young man whose charm and intellect brought him into the elegant circles of Paris. In the group that collected around Jeanne de Lespinasse, Bordeu met such philosophes as Denis Diderot and Jean d'Alembert, the editors of the Encyclopédie. Partly because of that association, his medical philosophy grew in reputation and influence in Paris and outside of France. Some of his most fundamental ideas found their way into the Encyclopédie and helped to shape the physiological viewpoint adopted in that widely read work..$^{50}$

In his mature physiological system, vital function was associated with an active force of sensibility, which Bordeu believed resides in every animal organ. He considered that this sensibility responds to stimuli, thereby activating a force of irritability or contractility that always accompanies it. Together, they provoke the motions that constitute an organ's vital action. The notion that sensibility and irritability are fundamental physiological properties of the structural elements of the body had already coloured and shaped much of the work of Glisson and of others, including Helmont and Harvey. In the eighteenth century in general, these forces were to be subjected to very extensive study by many persons. I shall examine some of them in the next chapter. Here, however, I wish to consider the way in which Bordeu incorporated the phenomena of sensibility and irritability into his particular vitalist and organicist system.

Bordeu's 1743 doctoral thesis, the Chilificationis historia, offered its readers a nonmechanist theory of the secretion of the bodily juices. In it, Bordeu located the soul, which directs glandular and other activity in the nerves. The youthful thesis was expanded into the book which medical historians have widely judged to be Bordeu's most important contribution to physiology. Recherches anatomiques sur la position des glandes et leur action was published in 1752, soon after Bordeu became

\footnotetext{
${ }^{30}$ Anthelme Richerand, 'Notice sur la vie et les ouvrages de Bordeu', Oeuvres complètes, op. cit., note 40 above, vol. I, pp. i-xxiv; E. Forgue, 'Théophile de Bordeu (1722-76)', Les biographies médicales, Paris, Baillière, 1937, pp. 97-128. The work of Sauvages and Bordeu, along with that of Whytt and Gaub, are briefly discussed with respect to their transition to vitalist models in Hall, op. cit., note 4 above, vol. 2, pp. 66-86. Théophile de Bordeu, Correspondance, ed. by Martha Fletcher, 4 vols., Montpellier, Université Paul Valéry, 1980, is insufficiently edited. Nevertheless, it reveals a great deal about Bordeu's personal life and the practical circumstances surrounding becoming a successful physician in eighteenth-century Paris, especially if one were from the provinces. The letters tell us nothing about Bordeu the scientist.
} 


\title{
Animism, vitalism, and the Medical University of Montpellier
}

established in Paris. He lucidly expounded there his basic theory about the nature of life and the vital processes. The glands served as models for describing the functions of all the organs of a body. He carefully and decisively demonstrated that the traditional mechanist theories which treated glands as complicated sieves were simplistic and completely inadequate. Having done so, he went on to account for glandular secretion and excretion of humours, as well as of all other vital activity by referring to the sensibility that is part of their organization.

By studying glands, Bordeu was taking up one of physiology's most challenging questions. The body produces many different humours, all of which are critical to its wellbeing. Understandably, it was generally felt that if one could begin to comprehend the means whereby one gland is able to produce a secretion quite different from that of another gland, one could begin to fathom something fundamental about life's mysterious processes. Descartes and Borelli, in the seventeenth century, offered the simplest explanation of all. They visualized the glands as sieves in which situation, size, and shape of the pores determined what passed through them. But that hypothesis could really do little more than explain why large particles cannot pass into glands that have small openings. A considerable amount of important work on the anatomy and physiology of glands was subsequently done by other mechanists including Malpighi, Ruysch, Morgagni, and Boerhaave. ${ }^{31}$ According to Bordeu, Boerhaave's theory was the one which was generally accepted in the mid-eighteenth century. Although he admitted that glands are more than mere sieves, he predictably still tried to understand their complex operations mechanistically:

\begin{abstract}
Hence the Humours will be various according to the Discharge of the Artery from the Heart, its Situation with respect to the Heart and the Trunk from whence it arises, its different Complications \& Number of Ramifications before it terminates, the different Velocity of the Blood moving through it, the Proportion that the single Branch bears to its Trunk, the different propelling Forces, both external and internal, which discharge the Humours, the different Time of its standing in the common Cavity or Receptacle, \& the various Passages it goes through, from whence making new Changes, with the different Degree of Absorption or Exhalation of the more fluid Parts from the secreted Juice; all these Causes, I say, concur to produce the vast variety of Humours observed in the several Parts of the Body, from that one common Mass the Blood, whose Particles are thus variously sorted, separated, \& combined in as wonderful Manner. ${ }^{32}$
\end{abstract}

Once the glandular humour was thus secreted or manufactured, it had to be released by the gland into the body to carry out its functions. Boerhaave discussed the excretion process of the salivary glands in a work dealing with the larger question of digestion. He thought that the salivary juices are pressed out of their glands into the mouth by jaw movements during chewing. He presumed that this activity constricts certain muscles around a gland thereby compressing it. As the collected humour is expelled by the pressure, the gland is stimulated again to secrete more saliva from the blood. ${ }^{53}$ It followed that lachrymal glands must secrete tears in response to a pressure

\footnotetext{
${ }^{51}$ Luigi Belloni, 'Boerhaave et la doctrine de la glande', in G. A. Lindeboom (editor), Boerhaave and his time, Leiden, Brill, 1970, pp. 69-82. Belloni analysed the mechanistic glandular theories of Malpighi, Ruysch, Boerhaave, and a few other mechanists. Boerhaave's particular conception of glandular function is also discussed in Lindeboom, op. cit., note 25 above, pp. 264-268; and in King, op. cit., note 25 above, pp. 59-93.

s2 Boerhaave, 'Of the different structure of the glands', Academical lectures, op. cit., note 26 above, vol. 2, p. 234.

${ }^{33}$ Boerhaave, 'Of the origin, nature and mixture of the saliva with the aliments', ibid., vol. I, pp. 135-156.
} 


\section{Xavier Bichat}

around the eye, and so on. Albrecht von Haller, Boerhaave's most famous student, offered a similar explanation of glandular phenomena in his First lines of physiology of 1747.54

Though this tortuous striving after mechanical explanation did not commend itself to Bordeu, he admitted that Malpighi, Ruysch, Morgagni, and Boerhaave ought to be consulted on the subject of glandular activity. It was simply that they had not succeeded in accounting for its complexity. Bordeu set out to show first of all that the mechanist's approach was erroneous and then to substitute a more satisfactory vitalist explanation. Bordeu dealt first with the question of excretion of juice from the gland in which it had already been manufactured and stored. With painstaking skill he demonstrated that the anatomical space in which a gland is located can be neither altered in shape nor diminished in size. Nature has located glands in such a way that no muscles or other structures can press upon them. He referred to an experiment done eight years earlier in Montpellier, perhaps while he was preparing his doctoral thesis, in which a water-soaked sponge was inserted into a parotid gland cavity. No amount of jaw movement could extract even a drop of that water from it. Bordeu took his readers on an anatomical tour of the glands. Moving from the head downwards, he examined the lachrymal glands, the pituitary, thymus, thyroid, pancreas, suprarenals, and so on. He even examined the brain, though he pointed out that he did not himself believe it to be a gland. Malpighi and Boerhaave, among others, had so classified it because of its alleged production of animal spirits. In any case, in every one of the organs examined, Bordeu's evidence was quite decisive. Under normal circumstances, no gland is ever subjected to any physical pressure, so that the explanation for glandular activity must be sought elsewhere. ${ }^{55}$ The evidence seemed to strike a decisive blow against mechanism.

How, then, can one account for glandular phenomena? Bordeu used the testicles and mammary glands as models to describe what occurs in the process of secretion in general. He believed that the sexual organs demonstrate clearly the combination of excitation, irritation, sensibility, and nervous action which are critical for an organ's function. The process of excretion proceeds in four steps. There is a spasmodic action of the gland or an erection; this produces a shaking or some other sort of irritation; the disposition of the excretory organ alters so as to facilitate humoral flow; and finally, there are some necessary changes in the vessels. He applied the model to the salivary glands, claiming that first, there is a kind of tickling around the parotid when one begins to eat, causing the gland to undergo a kind of erection or awakening; jaw movements provide friction, which is an irritation; the glands are prepared to excrete saliva, and finally, the vessels going to the gland allow more blood to collect around it and less to flow out so that more saliva can be manufactured. Lachrymal glands are irritated by air, inflammation, laughter, and coughing. He was convinced that in every gland, some appropriate irritation is always there to activate the force of sensibility, which is then responsible for excretion and for further production of the glandular

\footnotetext{
s4 Lester S. King, 'Introduction', to Albrecht von Haller, First lines of physiology, trans. and ed. by William Cullen, Göttingen, Wrisber, 1786, reprinted New York and London, Johnson Reprint Corp., 1966, pp. 109-134.

ss Bordeu, op. cit., note 40 above, pp. 50-130.
} 


\section{Animism, vitalism, and the Medical University of Montpellier}

humour. In summary, he wrote as follows: "Glandular excretion . . . does not proceed, as has been asserted, by the compression of glandular bodies, but by the proper action of the organ, action augmented by certain circumstances, such as irritations, jolts, and the disposition of the vessels of that same organ." 36 It is worth noting that though Bordeu maintained vigorously that physical glandular compression cannot be part of the excretory mechanism, he permitted a shaking and jolting to serve as the signal for irritability. If that is somewhat of a contradiction, it seems to have escaped Bordeu.

In the second stage of his investigation, Bordeu took up the question of how an organ secretes, that is to say manufactures, its humours. He considered that the force of sensibility was as important in this first stage of glandular activity as in the final one. Following on Boerhaave's observation that glands have more nerves in proportion to their bulk than do any other parts of the body, Bordeu remarked that the Creator surely would not provide so many nerves without giving them a function. ${ }^{37}$ They are, he believed, the instruments that transport the critical signal of sensibility. The most compelling of six "proofs" advanced on behalf of their glandular role was simply that cutting the nerve supply to a gland stops its function. Another was that in sleep, a state assumed to be the result of relative nervous inactivity, the secretions of such as the salivary glands seem to be slowed. Bordeu neglected to mention, however, that the secretion of the digestive organs and kidneys are not so affected. He also thought it probable that nerves prepare a gland to make a kind of choice of appropriate material from the circulation. They are, therefore, the principal cause of the separation of the proper parts from the blood. In each orifice of each gland, there must be a particular type of small sphincter and several nervous fibrils which cause it to dilate or constrict depending upon the irritation of the nerves. The choice thus made by the organ is governed by what Bordeu called "a type [espèce] of sensation".s8

Bordeu assumed that a similar indwelling sensitivity exists in every organ of the body. Nervous fibres are its instrument. It is unique in each organ, and therefore capable of performing its particular function. It is accompanied by an irritability which it activates, causing it to move the parts of the organ. ${ }^{59}$ Sensibility is, therefore, the force that directs all organic functions. It even dominates in illnesses and directs the action of remedies. ${ }^{60}$

Because microscopy had revealed nervous filaments to be solid structures, Bordeu rejected the theory of animal spirits to which so many physicians had assigned deplorably vague and even contradictory properties. He believed that nerves act by means of motion. All organs possess a basic vital tension that is imparted to them by the brain by means of nerves' motion. This motion derives first from the force of the blood due to heartbeat; hence, as long as the heart beats, the brain experiences the blood's motion. This general vital tension maintains muscle tone and, indeed, life in general. The sensation, irritability, and activity of the various organs derive from a

s6 Ibid., pp. 121-146.

${ }^{57}$ Boerhaave, op. cit., note 52 above, pp. 210-211.

s8 Ibid., pp. 196-201.

59 Bordeu, 'Recherches sur le pouls par rapport aux crises', in Oeuvres complètes, op. cit. note 40 above, vol. I, pp. 420-421.

${ }^{60}$ For example, see ibid., pp. 420-421; 'Recherches sur l'histoire de la médecine', in Oeuvres complètes, op. cit., note 40 above, vol. 2, p. 669 . 


\section{Xavier Bichat}

motion in excess of that basic tone. ${ }^{61}$

Like the mechanists, Bordeu treated the soul as a rational and spiritual being, involved in every conscious function. "Other functions", however, "seem to depend upon purely vital sensibility without it appearing that the soul has any role at all to play." 62 However, the soul frequently modifies even the latter functions. For example, Bordeu specifically linked the soul's activity to the phenomena which the body experiences in emotions, and claimed that each emotion or passion is connected with an organ so that some emotions suspend digestion, others produce tears, and so on. These effects are mediated through nerves, although, like all conscious sensations, emotions originate in the brain.

Bordeu continued to develop his sensibility thesis over the years. In time, he came to see the living body as a collection of organs, each of which possesses its own particular and separate life. "The living body", he wrote in 1775, "is a collection of several organs which live in their own way, which experience more or less sensation and which move, act and rest in determined times ... the general life (of the organism) is the sum of all the particular lives." ${ }^{3} \mathrm{He}$ went so far as to locate the centre for these disparate sensibilities in the region of the stomach. "We place there the seat, the end point, the support of almost all the body action, of almost all the sensations; the play and tumult of the emotions." 64 For the body functions as a whole, Bordeu discerned a total of three co-ordinating centres. "The brain, the heart and the stomach are ... the triumvirate, the triple support of life ... the three principal centres from which consciousness and motion flow and to which they return after having circulated."65

The similarity between these latter notions and Helmont's visions is more than mere accident. Bordeu wrote of Helmont in superlatives, crediting him perhaps too enthusiastically with the overthrow of Galenism and the creation of a new medicine. This lends weight to the contention that Bordeu's concept of general sensibility was fashioned after the grand archeus and the proper sensibilities of the specific organs were based upon the individual archei. ${ }^{66}$

It is interesting that in his search for alternatives to the prevailing physiological systems, Bordeu should look to the vision of a man who had challenged orthodoxy over a century earlier. Bordeu's language, of course, sits more comfortably with us than that of Helmont. Whereas we can cope with "sensibility", the vague and mysterious archei are thoroughly fanciful. Nevertheless, it was there that Bordeu found the idea that one must search for the life of a body in its own parts.

Bordeu's physiological system had considerable influence upon his own century. He was seen as the most eminent representative of what became known simply as the

${ }^{61}$ Bordeu, op. cit., note 40 above, pp. 196-201.

${ }^{62}$ Bordeu, op. cit., note 60 above, pp. 667-669.

${ }^{63}$ Bordeu, 'Recherches sur les maladies chroniques', in Oeuvres complètes, op. cit., note 40 above, vol. 2 , p. 829. For an interesting examination of the psychological consequences of this physiological theory, see Paul Hoffmann, 'L'idée de la liberté dans la philosophie médicale de Théophile de Bordeu', Studies on Voltaire and the Eighteenth Century, 1972, 89: 769-787.

${ }^{64}$ Bordeu, op. cit., note 63 above, p. 801 .

${ }^{65}$ Ibid., pp. 829-831.

${ }^{66}$ The connexion between the notions of Helmont and of Bordeu was made by Marie-Jean-Pierre Flourens, 'Coup d'oeil historique sur l'étude analytique de la vie', De la vie et de l'intelligence, Paris, Garnier Frères, 1858, p. 51. 


\section{Animism, vitalism, and the Medical University of Montpellier}

Montpellier school. One of its representatives, Dr Ménuret de Chambaud (1733-1815), wrote more than forty articles for the last ten volumes of the Encyclopedie, thereby using this widely read work to propagate the new physiology. He conceived of a motor faculty regulating unconscious vital motions. It was equated with Glisson's irritability, which was taken to be synonymous with "sensibility", "mobility", and "contractility". Diderot commissioned another Montpellier professor, Henri Fouquet (1727-1806), to write the articles on 'Sensibilité and 'Secretion' for the Encyclopédie. Fouquet tended to regard sensibility as a kind of sensitive soul, rather more a substance than a property of matter. Most of his other ideas, however, including those having to do with secretion, faithfully followed Bordeu. ${ }^{67}$ Many other people, including Bichat, examined many of these notions over the years as they became part of the language of medicine.

In spite of Bordeu's considerable impact on the medical world in general, his views were eclipsed in Montpellier by those of Paul-Joseph Barthez (1734-1806), who was to give the vitalist theory still another form. Barthez did not share Bordeu's admiration for Helmont, and he dismissed the numerous specific organic sensibilities as a vain multiplication of causes. He preferred to attribute the functions of life to a single principle. That principle, however, was different from the soul or anima.

Barthez was born in Montpellier and received a medical doctorate from that university in 1753. After serving some years as a physician and a medical consultant to the French army, he applied for the chair of medicine at Montpellier in 1759. When he finally received the position two years later, he joined a faculty of men whose professional relationships were most remarkably and openly petulant, selfish, and even vindictive. Few things aroused their outrage and indignation so much as having one of their number displaced in an academic procession by a man of junior rank. Barthez created considerable animosity because he served as survivancier to JeanFrançois Imbert, who was chancellor of the university from 1761 to 1785 . Whenever Imbert was absent from the university, Barthez enjoyed all the privileges of his rank. When Imbert returned, Barthez' status reverted to that of a junior instructor. Barthez and his colleagues alternately played the situation for what it was worth so that he became a kind of social yoyo. Remarkably, Barthez thrived and prospered in that atmosphere. Various people who knew him have described him as a short and ugly man with an angry, vindictive, ambitious, and jealous nature, ${ }^{68}$ but he was also an excellent teacher with a prodigious memory and a remarkable capacity for work. It was a combination of qualities which earned him a reputation unsurpassed at the University of Montpellier to this day.

Over the years, he became physician to the Duc d'Orléans, chancellor of the University of Montpellier, consulting physician to the king, a member of the National Health Council, and finally, a State Councillor. He spent most of his time in Paris, leaving his duties, meanwhile, to survivanciers. He passed the revolutionary years in

\footnotetext{
${ }^{67}$ The Montpellier physicians are discussed in relation to Diderot by Roger, op. cit., note 7 above, pp. 619-641. Ménuret, Fouquet, and Lacaze in particular are discussed on pp. 631-641.

${ }^{68}$ A young student described Barthez in 1758 as a man "mal bati, de vilaine figure, sourd d'un côté, entendant mal de l'autre, ayant de mauvais cheveux mal plantés, done cependant il est amoureux, en habit noisette à boutones d'argent". Quoted by Alice Joly in "Un étudiant lyonnais à Montpellier au XVIII" siècle', Monspel. Hippocr., 1970, 13: 11-23.
} 


\section{Xavier Bichat}

Narbonne, presumably avoiding the capital because of his favoured status in the former regime. In 1801, he was named a member of the Institut National de France, and thereby restored to the profession. He served as a consultant physician to Napoleon under the Empire and in 1802, he returned to the faculty of Montpellier. ${ }^{69}$

Barthez' memory is today much revered at Montpellier. His larger-than-life statue, erected in 1856, stands guard at the entrance to the school. A street and a reading room are named after him, and his bust looks down in various parts of the school. More importantly, his contribution to medical philosophy is still frequently alluded to by members of the medical faculty. In 1971, for example, one wrote that "The essential ideas which he uttered have today become so evident that they are contested by no one. Only the history of medicine is there to recall that it was not always so."70 If asked to account for his enthusiasm, the writer of those words would be unlikely to claim that life is linked to a vital principle which may be material in nature and whose forces transcend physical ones. But just such a principle was Barthez' preoccupation in his work, especially in the Nouveaux élements de la science de l'homme.

In Paris, Barthez was a close friend of Jean d'Alembert, an exponent of Newtonian philosophy. Barthez is alleged to have acquired the germ of his mature ideas about life from him. ${ }^{11}$ Indeed, Barthez also claimed for himself the medical mantle of Newton, believing that he was working in accordance with the great man's principles. The object of natural philosophy, he wrote in the preliminary discourse, is research into the causes of natural phenomena. Immense progress has been achieved in astronomy, for example, because a multitude of observed effects came to be assigned to a few experimental causes such as gravity. That is the essence of scientific progress, which consists in the establishment of more and more general laws that account for more and more phenomena. Thus the number of causes necessary to explain phenomena diminish progressively. To emulate Newton was, for Barthez, to search for forces or causes that would account for a multitude of physiological responses as coherently as the gravitational force explained physical and astronomical ones.

The "good philosophical method" had eluded the ancients, Barthez wrote, because they were too apt to multiply causes. More recently, other persons had erred in the opposite direction. For example, the mechanists tried to relate all animal activity to the force of impulsion while the animists resorted to a single ubiquitous soul. Most interestingly, Barthez also warned his readers against the new sect of the "solidists". Neither mechanists nor animists, its members attached great importance to Helmont's notion that each organ has a life proper to it, in addition to the separate particular life belonging to the entire body. Unmistakably, he was thinking of Bordeu and of other similarly-minded members of the Montpellier school. He took their work to be a form of misleading and pointless multiplication of motive forces. ${ }^{22}$

Barthez sought to replace these various flawed theories with his notion of the vital

${ }^{69}$ The biographical material is taken largely from Louis Dulieu, 'Paul-Joseph Barthez', Revue Hist. Sci. applic., 1971, 24: 149-176. A complete bibliography of Barthez' published works appears at the end of the article.

${ }^{10}$ Ibid., p. 170.

"Flourens so argued in op. cit., note 66 above, p. 83

${ }^{72}$ As well as the members of the Montpellier school, Barthez must have had in mind the works of Francis Glisson, Julien Offray de la Mettrie, and Denis Diderot. 


\section{Animism, vitalism, and the Medical University of Montpellier}

principle, which he regarded as the most general of experimental causes. He believed that it coexists with the body and the rational soul and that it possesses both sensitive and motor components. The respective functions and the inter-relationship of body, soul, and vital principle were the main subject-matter of the Nouveaux elements.

Barthez used the word "principle" to denote simply an experimental cause of motion. Nature employs several of them, the most simple being impulsion, whereby an object is moved by physical contact. The slightly more complex force of attraction accounts for gravity, for particular affinities, and for the phenomena of magnetism and electricity. Still more complex forces form ice crystals and angular crystallized salts. The highest and most complicated force in nature is the vital principle, which is found in plants and animals and whose functions cannot be accounted for more simply. ${ }^{73}$ It is more complicated in man than in animals, and least complicated in plants. ${ }^{74}$

Barthez did not, however, claim the discovery of the vital principle distinct from both body and soul for himself. He recognized it in Francis Bacon's claim that man has an irrational, corporeal soul in addition to his rational, spiritual one. Albeit "carried away by ideas approaching delirium", Helmont had glimpsed the truth when he claimed that man is endowed with a principle of life distinct from both body and soul. More recently, Hoffmann had speculated that the life principle occupies a place between that of body and soul. Even some physicians from Boerhaave's school, and Barthez especially had in mind Gaub, Boerhaave's successor at Leiden, attached a vital principle of some sort to the body. ${ }^{75}$

Barthez appears to have adopted the theory of a vital principle simply because he was uncomfortable with the idea that the source of motion of a body resides in its matter. On the other hand, he turned his back on animism because he could not imagine that the soul, an instrument of the will as he understood it, can participate in automatic activity. It has no sense of internal vital motions and it can neither suspend nor modify the motion of, for example, the heart and intestines. Nor can it account for the frequent conflicts an individual experiences between his will and his appetites. Recall here Sauvages' examples of the criminal walking unaided to the gibbet and the patient to the operating table. Sauvages had dealt with this conflict by subdividing the soul into faculties that presumably spar with one another. Finally, Barthez pointed out that animism cannot account for the ability of parts recently separated from a body to move and to respond to stimuli. He offered the examples of the decapitated chicken and the extirpated heart, and claimed even to have seen movement in the head and trunk of a decapitated man. He thus opted for a living principle distributed throughout the body. ${ }^{76}$

\footnotetext{
${ }^{33}$ Paul-Joseph Barthez, 'Discours préliminaire', in Nouveaux éléments de la science de l'homme, Montpellier, J. Martel ainé, 1778, pp. i-xxviii. For a discussion of Barthez' views concerning the nature of the vital principle, see Réjane Bernier, 'La notion de principe vital de Barthez', Archs. phil., 1972, 35: 423-441; and Elizabeth L. Haigh, 'The vital principle of Paul-Joseph Barthez: the clash between monism and dualism', Med. Hist., 1977, 21: 1-14. The work of Bordeu is discussed, together with that of Barthez, by Duchesneau, op. cit., note 2 above, pp, $361-430$.

74 Barthez, op. cit., note 73 above; pp. $1-6$.

${ }^{75} \mathrm{~L}$. J. Rather, Mind and body in eighteenth-century medicine, a study based on Jerome Gaub's De regimene mentis, London, Wellcome Institute, 1965.

${ }^{76}$ Barthez, op. cit., note 73 above, pp. 28-35.
} 
What then is the nature of this vital principle? Does it have some centre or focus? If the extirpated heart was not beating as a consequence of either an indwelling sensitivity or a soul, the only other explanation was that it must retain some part of the vital principle within it. The principle, therefore, must be divisible. The force exists, Barthez wrote, in solid and fluid parts of the body alike. It is, for example, the source of the motion of the blood." The vital principle is endowed with both sensitive and motor forces which interact to produce the complex phenomena that we observe as life. Barthez distinguished between sensibility and irritability. Although each organ possesses at least minimal sensibility, the force is most abundant in the brain and the nerves. Meanwhile, all the solid parts of the body possess some amount of the motor force. In structures such as bones, however, it exists only to nourish the parts and to effect regeneration if the bones should be damaged..$^{78}$

In all cases, Barthez believed, there is a connexion between the two forces of the vital principle such that mobility depends upon sensibility. The extirpated heart, for example, continues to beat because some of the vital principle remains in it and "this part, when these members are irritated, is caused to move by the sentiment it has of an irritation". Sensibility, therefore, is not necessarily conscious. But by so speculating about the existence of unconscious sensibility, Barthez was moving perilously close to the position of Glisson and of Bordeu. Indeed, he wrote of the sensibility proper to each organ which exists apart from the nerves. Its existence is particularly clear in the case of certain small animals such as shellfish, which have a sensibility in spite of having no nerves at all. But that would be clearly our interpretation rather than Barthez' own.

The motions of the bodily parts, Barthez wrote, are of two sorts. The first is very rapid while the second is too slow even to follow. The former occurs in the motion of the muscles, the iris, the intestines, the heart, and so on. It is impossible to account mechanically for the enormous forces which the vital principle exercises in the contraction of various muscles. For example, the chewing of bones, the strength of someone suffering convulsions. the lifting of heaving weights, and so on, would break or tear those same bodily parts if the supra-mechanical life force were absent. The slow motions, on the other hand, are tonic forces that exist in all the parts, providing a degree of cohesion which external agents tend to weaken. One observes them in blood vessels, in the cellular tissue of the skin, in voluntary muscles, and wherever a basic tone must be maintained. Weakened during serious illness, they are also strengthened by exercise, which forces an increase in the cohesion of the muscular parts. So it is that the body can literally and properly be said to fall apart at death. ${ }^{79}$

The vital principle moves the humours of the body including the blood, and it maintains a suitable degree of heat in the body by agitating its solids and fluids..$^{80}$ Finally, it maintains the unity of the body by means of sympathetic connexions between the parts. The voice changes in puberty, for example, in response to changes in the sexual organs; abscess of the liver frequently follows a wound in the head;

\footnotetext{
77 Ibid., pp. 101-117.

78 Ibid., pp. 42-63.

79 Ibid., pp. 64-100.

${ }^{80}$ Ibid., pp. 118-141.
} 


\section{Animism, vitalism, and the Medical University of Montpellier}

inflammation in one eye will produce the same symptoms in the other; if the pupil of one eye responds to light, the other will follow suit, and so on. Barthez labelled these "sympathies", and alleged that they travel by means of nervous pathways. There is a perpetual reciprocal communication between the tonic forces of the nerves and a constant antagonism that keeps these forces in equilibrium. ${ }^{81}$

It might well be objected that so far, Barthez had claimed nothing which would make it necessary for him to reject the basic arguments of other members of the Montpellier school. After all, both he and Bordeu believed that irritability and sensibility are distributed in all the organs and parts. At one point, Barthez even wrote of the vital principle acting on what he called the molecules, that is to say, on the smallest parts of the muscular fibres so as to disperse them and to bring them together again. ${ }^{82}$ Why not, then, simply say with Bordeu that a vital motion is a consequence of the sensibility resident in the moving part? As we have seen, Barthez apparently did not do so, insisting instead upon a separate vital principle, simply because of his conception of matter as inert substance.

He did, however, offer other bits of evidence in support of the assumption that the body and its motive force are separate entities. In so doing, he began to sound very much like Sauvages. He remarked, for example, that life and consequently the vital principle can be destroyed with no alteration of the integrity of the body, using Sauvages' example of the recently drowned man whose body is still intact. On the other hand, Barthez went on, the vital principle can survive a long time, even with substantial lesions of such essential organs as the heart and brain. Barthez also remarked on what he called a "pre-established harmony" which exists between the vital principle and motions in relation to organs that do not yet exist. For example, a small bird will make flapping motions when its wings are still too feeble to support it, and a calf will playfully butt with non-existent horns. Barthez took these examples to be evidence of the vital principle's independent existence, rather than simply being a modality of the living man..$^{3}$

Barthez conjectured that the vital principle might be material in nature. In fact, many of his assumptions concerning its behaviour were only consistent with such a belief. He thought, for example, that it exists in a latent or concentrated state in pupae and birds' eggs, where it awaits animal heat to form and give life to an organism. He wrote in various places of lesions of the vital principle and of poisons acting to destroy it. As one commentator observed, one cannot concentrate, produce lesions in, or poison an immaterial principle. ${ }^{84}$

Barthez remarked that muscular motion is extinguished when nervous connexions to muscles are severed or when blood vessels are ligatured. Other organs such as intestines or the heart, however, are more independent and durable. It must be, he thought, because the latter, having more of the vital principle within them, depend less upon sympathetic connexions with other organs. Barthez tied this alleged quantity of the vital principle to the phenomenon ot sleep, reasoning that it is the organs with the

${ }^{81}$ Ibid., pp. 142-172.

${ }^{82}$ Ibid., pp. 68-69.

${ }^{83}$ Ibid., pp. 27-41.

${ }^{84}$ Bernier, op. cit., note 73 above. 
greatest proportion of vitality that require least rest. Considering sleep to be the repose of muscles, he thought that it is produced by alterations in the brain. Such organs as the heart, arteries, respiratory muscles, and so on, must continue to act without respite, however. Hence the larger amount of the vital principle allotted to them. ${ }^{85}$ A relatively trivial speculation by Barthez, this theme was subsequently developed by his student Jean-Charles Grimaud. Twenty years later, Bichat, in turn, considered the nature of sleep and in imitation of Grimaud, used it to develop his crucial division of life into animal and organic categories.

Finally, Barthez discussed death, defining it as the irrevocable cessation of sensibility and of vital motions. His uncertainty about the precise nature of the vital principle, however, prevented him from knowing its fate when life leaves the body:

If this Principle is only a faculty united to the living body it is certain that it perishes with the body. If it is a being distinct from the body and the soul, it may perish outside the extinction of its forces in the bodies which it animates; but it may also pass into other human bodies and vivify them. ... It is possible that the end of the vital principle is related to its origin. Thus in supposing that it may have emanated from a principle which God created to animate the worlds, it may be rejoined to the Universal Principle at death. ... Whatever the destiny of the vital principle of man is at death, when his body returns to the earth, his soul returns to God who gave it to him and who assures him immortality. ${ }^{86}$

Believing his vital principle to be capable of unifying existing knowledge and of directing future observation and experiment, Barthez compared its alleged discovery to Newton's discovery of universal gravitation. He was convinced that his vital principle distinguished his system from all previous ones. Nevertheless, it is clear to us that it does not belong on the same ontological plane as, say, Newton's laws of motion and that, in fact, Newton would have consigned the vital principle disdainfully to the scientific rubbish heap of hypotheses.

The naturalist Georges Cuvier put his finger on the difficulty attached to postulating the existence of the vital principle. He pointed out that gravity is defined precisely so that the motion of bodies towards each other is described in accordance with a specific law. The vital principle, on the other hand, was described only in the most general terms. Furthermore, he questioned the validity of postulating a system which is neither material nor immaterial, neither mechanical nor intelligent. To say that the phenomena of muscular contraction, sensibility, curing of wounds, formation of the foetus, reproduction of the species, and so on, are all effects of a simple, single principle is merely to enumerate phenomena, not to explain them.$^{87}$

Although we must concur with Cuvier's criticism, it is important not to lose sight of the intellectual authority that Barthez wielded, especially in Montpellier where his ideas commended themselves to generations of students. One of his students, who is important for our purposes because he assists us in understanding Bichat, was JeanCharles Grimaud (1750-89). When Barthez became chancellor of the University of

${ }^{8 s}$ Barthez, op. cit., note 73 above. pp. 234-244.

6 Ibid., pp. 347-348.

${ }^{87}$ Georges Cuvier, 'Histoire de la classe des sciences mathématiques et physiques', Mém. Inst. Nat. Sci. Arts: Sci. math. phys., 1806, 7: 1-79. A translation of pp. 76-79 is found in William Randall Albury, 'Experiment and explanation in the physiology of Bichat and Magendie', Stud. Hist. Biol., 1977, 1: 105-106. See also, Georges Cuvier, 'De Barthez, de Médicus, de Desèze, de Cabanis, de Darwin et de leurs ouvrages', Histoire des sciences naturelles, 5 vols., Paris, Fortin, 1843, vol. 4, pp. $27-46$. 
Montpellier in 1785, Grimaud was awarded his anatomy chair. That year, the Imperial Academy of Sciences in St Petersburg invited the medical community of the world to consider the following question:

Since nutrition and growth occur in various parts of the animal body which have no vessels such as the epidermis, nails, hair, hooves as well as those with a small number of vessels like bones: as well as the rapid growth of the embryo at a time before there is a heart or vessels, it must be that there is a force proper to the animal substance which brings nourishing juices to all the parts in proportion to their growth. ... What is this force? Is it the same as that of attraction or is it properly and uniquely due to the living substance of animals and plants? Are there perhaps different forces ...?

It was a particularly suitable challenge for persons who had studied at Montpellier, and Grimaud duly sent a memoir to the Russian academy. A version was later published as a Memoire sur la nutrition in Montpellier in 1787.

At the beginning of the work, Grimaud divided animal functions into internal and external, meanwhile warning his readers that the division is merely a device to assist us in ordering our ideas. By means of its external functions, an animal encounters the surrounding world. It "moves out of itself, it extends itself, it enlarges its existence, it carries and shares it with the objects which surround it; it studies these objects." This is achieved by means of the senses and with locomotion, all of whose activities are controlled by the brain. ${ }^{88}$ Internal functions, including nutrition, glandular secretion, respiration, and reproduction, maintain the organism. In imitation of Bordeu, he speculated that they are controlled from a sensory centre at the superior orifice of the stomach.

Grimaud, then, proceeded to distribute the sensible and motor forces between the internal and external functions. An animal motor force (force motrice animale), he wrote, produces external functions by agitating fibres; it is paralleled in the internal life by the vital motor force (force motrice vitale) whose activity completely escapes consciousness and over which the will exercises no control. Its principal object is to distribute nourishing juices to all the parts, and it is subordinated to an internal vital sense (sens vital interieur) whose activity is also apart from consciousness and the will. ${ }^{89}$

In a second Mémoire sur la nutrition and in a Cours complet de physiologie, Grimaud discussed the two lives in relation to sleep. "Sleep", he wrote, is a state or "effort of the internal parts just as wakefulness is an effort of the external parts." The two states, and hence the two lives, dominate each other alternately. So it is that the state of the foetus and that of plants is one of uninterrupted sleep. ${ }^{90}$

Bichat's vital theory was rooted in the same distinction between external and internal functions which Grimaud described. He did not, however, treat them as merely a convenient classificatory device. Rather, he believed them to be a fundamental division rooted in nature itself. ${ }^{91}$ Bichat's five vital properties, in fact, were based upon the animal-organic division. The correspondence between Grimaud's force motrice vitale. force motrice animale, and sens vital intérieur and Bichat's organic contractility.

\footnotetext{
*3 Jean-Charles Grimaud, Mémoire sur la nutrition, Montpellier, Jean Martel, 1787, pp. 2-3. See also, Grimaud's Cours complet de physiologie, 2 vols., Paris, Méguignon-Marvis, 1818, vol. 1, pp. 37-53.

"Grimaud (1787), op. cit., note 88 above, pp. 19-40.

90 Ibid., pp. 140-155; and idem (1818), op. cit., note 88 above, pp. 195-210.

91 Bichat, op. cit., note 1 above, pp. 1-9.
} 


\section{Xavier Bichat}

animal contractility, and organic sensibility respectively is unmistakable, ${ }^{92}$ and there can be little doubt that Bichat was familiar with Grimaud's speculations.

Grimaud's answer to the problem posed by the St Petersburg Academy was a digestive force which belongs to the internal life and to which he attributed all the complex activity surrounding the ingestion and assimilation of food. He described its functions much like he did those of the force motrice vitale. It is not altogether clear, therefore, why he chose to distinguish between them. Bichat would dismiss this as the vain multiplication of forces, arguing, in a manner reminiscent of Barthez, that contractility and sensibility alone are sufficient to account for all living phenomena.

Other people, however, were even more guilty than Grimaud of multiplying forces, faculties, and principles. By the latter part of the eighteenth century, traditional mechanism had been superseded by the imagery of active tissues whose activity is not reducible to that of the non-living world. By the 1890 s, Montpellier was unequivocally a vitalist school, and it was becoming complacent about its achievements. Perhaps it was a sense of confidence which lulled some of its younger faculty into a lazy use of language. An example is Charles-Louis Dumas (1765-1813), who obtained a medical degree from Montpellier in 1784, and acquired considerable skill and a reputation to match. A brief glance at Dumas' discussion of physiology demonstrates how careless Barthez' successors became with his vitalist thesis so that it became a complicated and even unwieldy device that could not order one's thoughts. Although Dumas wrote on a wide range of subjects, his basic theoretical position is contained in a four-volume Principes de physiologie published between 1800 and 1803 when he was Dean of the Faculty of Medicine at Montpellier. After he had offered the obligatory credit to Helmont, Stahl, and Haller, Dumas praised Bordeu, Lacaze, Barthez, and Grimaud for providing a solid base upon which to deal with organic studies. Borrowing from these various persons at random, he only succeeded in confusing their notions utterly.

Dumas was not, for example, particularly concerned about the nature of the vital principle, considering it to be merely an " $x$ " or unknown quantity somehow intermediate between the soul and matter. It has been variously labelled, he wrote, as a soul, archeus, vital principle, and so on.93 Because of its presence, an organism lives longer than its parts, which are continuously undergoing alteration, absorption, and excretion. At times hidden in a seed or a cocoon, its dormant vitality is able to stir and to reassert its primacy over the physical and chemical forces of the larger world. ${ }^{94}$

In any case, Dumas was more concerned with vital forces than with their source. In clear imitation of his teacher Barthez, he wrote that elementary particles of organized matter possess all the inorganic forces such as gravitation, attraction, repulsion, and inertia. ${ }^{95}$ To these, of course, are added the forces of sensibility and mobility. Dumas did not stop there, however. He also described an attracting force (force assimilatrice) and a force of vital resistance. Much like Grimaud's digestive force, the former oversees the transformation of food into bodily substance at the intimate level of tissues and organs. The latter was presumed to exist in order to retard corruption by prevent-

92 Ibid., pp. 129-133.

${ }_{93}$ Charles-Louis Dumas, Principes de physiologie, 4 vols., Paris, Deterville, 1800-03, vol. 1, pp. 115-143.

94 Ibid., pp. 159-248.

95 Ibid., pp. 266-278. 


\section{Animism, vitalism, and the Medical University of Montpellier}

ing certain fluids from coagulating, by keeping the stomach intact in spite of its solvent juices, and so on. ${ }^{96}$. And so, not heeding his mentor's frequent warnings about multiplying forces, Dumas fell into the trap of enumerating phenomena without explaining them.

Dumas was, reasonably enough, uneasy with Grimaud's external-internal classification of functions on the grounds that all functions overlap. Instead of dispensing with it, however, he expanded it to correspond to the four faculties of his vital principle. With the first division, he wrote, the animal establishes a relationship with its surroundings; with the second it maintains organic solids and fluids in their particular state; with the third, nature conserves the body by means of nutrition, sanguification, and excretion; with the fourth, it invokes a reciprocal relationship of affections and thoughts between persons. ${ }^{97}$

Classifications, of course, need not be treated as absolute categories. They are more properly devices for ordering one's thoughts. Even allowing for that, however, Dumas' system is an unnecessarily complicated one, careless in its terminology and cavalier in its categories. This very unwieldy quality, however, testifies to the thoroughness with which his predecessors at Montpellier had done their propaganda work. Vitalism being by then axiomatic, it had become the framework within which to work.

In view of its considerable reputation before 1800 , it is interesting that one encounters Montpellier virtually not at all in the nineteenth century. When the debate about the nature of the body and the means appropriate to study it were being vigorously pursued in Paris and elsewhere, Montpellier appears to have been unhealthily complacent. Its teachers, apparently, recycled what was by then a traditional form of vitalism, revering the memory of its great men and especially of Barthez. Student theses again and again invoked similar arguments on behalf of a unique vital principle. I admit that my impression may be false, based upon insufficient knowledge of the school after 1800. On the other hand, the statues, plaques, and eulogies produced in Montpellier in the last century suggest that persons there believed that their school had reached a peak in the work of Barthez.

Had it not been for the Revolution, Bichat would probably have followed in his father's footsteps and studied medicine at Montpellier. In any case, his ideas about the nature of the organism place him firmly within that school's tradition. Indeed, he was one of the last persons to insist, as a Montpellier physician might have done, that he was working within the context of the mechanist-vitalist debate. Writing on anatomy and physiology about the same time as Dumas, Bichat expressed far more coherent ideas. Nevertheless, the two men shared common intellectual roots. To Bordeu, Barthez, and Grimaud, Bichat owed many of his most compelling arguments on behalf of the existence of vital forces, their nature and their distribution. It is true that the ideas of the Montpellier school had become the stock-in-trade of physicians and philosophers at the time. Bichat's knowledge of their work, however, was so thorough as to suggest that their books were frequently at his elbow as he wrote and that what he was doing was basically elaborating and emending their notions. His achievement

${ }^{96}$ Ibid., vol. I, pp. 313-348; vol. 2, pp. 132-153.

${ }^{97}$ Ibid., pp. 67-84. 


\section{Xavier Bichat}

can be summed up as a marriage between their explicit vitalism with notions of tissue reactivity and a Lockian epistemology, both of which subjects are discussed in subsequent chapters. He produced, thereby, a system to which virtually all persons conversant with physiology and anatomy assented in the first decades of the last century. 